European

Neurology

Published online: July 25, 2012

\title{
Bruns Syndrome and Cysticercosis
}

\author{
Viroj Wiwanitkit \\ Hainan Medical University, Haikou, China
}

\section{Dear Sir,}

The recent report on Bruns syndrome and cysticercosis by Roongpiboonsopit et al. [1] is very interesting. This case is a good example of cysticercosis, a common but neglected tropical infection. Indeed, Bruns syndrome can be due to either parasitic or nonparasitic disease. MRI can serve as a tool to help find the cause of Bruns syndrome. Cysticercosis seems to be a common cause of Bruns syndrome in patients in the

tropics and should be included on the list of differential diagnoses. However, a problem is usually posed by a lack of concern in clinical practice. MRI can be easily interpreted since the other neurological infestation that can cause cystic lesions in the CNS is very rare [2]. Also, as in the indexed case, wholebody MRI might provide an additional advantage in identifying other possible concomitant visceral cysticercosis lesions.

\section{References}

1 Roongpiboonsopit D, Shuangshoti S, Phanthumchinda K, Bhidayasiri R: Positional vomiting as the initial manifestation of Bruns syndrome due to cysticercosis in the fourth ventricle: a symptom reminiscent of an old disease. Eur Neurol 2012;67:184-185.

$\checkmark 2$ Wiwanitkit V: Whole-body MR and cysticercosis. Pediatr Radiol 2010;40:1456.

\section{KARGER}

Fax +4161306 1234

E-Mail karger@karger.ch

www.karger.com (c) 2012 S. Karger AG, Basel

0014-3022/12/0683-0144\$38.00/0

Accessible online at: www.karger.com/ene
Prof. Viroj Wiwanitkit

Hainan Medical University Haikou, Hainan 570005 (China)

E-Mailwviroj@yahoo.com 